\title{
Memahami Strategi QISCUS untuk Unggul dalam Ketidakpastian Lingkungan Bisnis yang Tinggi
}

\author{
Luqman Tifa Perwira $^{1} \mathcal{E}$ IJK Sito Meiyanto $^{2}$ \\ 1,2Fakultas Psikologi Universitas Gadjah Mada
}

\begin{abstract}
Technology based company operates in a very dynamic business environment. As one of the fast growing technology company, Qiscus has proven themselves to be able to survived after several major change in their business. This study aimed to find out what strategies taken by Qiscus, as a startup company and how their strategy can be used to deal with this high uncertainty business environment. A qualitative method with case study approach was used to answer these research questions. Data were gathered from 8 informants ( 2 founders and 6 senior employees). Through the in-depth interview and observation processes, the study found six strategic themes which were then categorized into internal and external strategies. The research findings showed that Qiscus had implemented six strategies: high involvement organization, pivot, building brand image, maintaining users experience, strategic investment and market education. The findings support previous studies that stated organizations with strong internal stakeholder involvement tend to have better performance and productivity.
\end{abstract}

Keywords: high involvement; pivot; startup; strategy; uncertainty

Abstrak. Perusahaan berbasis teknologi informasi beroperasi dalam lingkungan bisnis yang sangat dinamis. Sebagai salah satu perusahaan teknologi yang berkembang pesat, Qiscus telah membuktikan diri mampu bertahan setelah mengalami beberapa perubahan besar dalam bisnis mereka. Penelitian ini bertujuan untuk mengetahui strategi apa yang diambil oleh Qiscus, sebagai perusahaan startup dan bagaimana strategi mereka dapat digunakan untuk menghadapi lingkungan bisnis dengan ketidakpastian yang tinggi ini. Metode kualitatif dengan pendekatan studi kasus digunakan untuk menjawab pertanyaan penelitian. Data dikumpulkan dari 8 informan (2 pendiri dan 6 karyawan senior). Melalui proses wawancara dan observasi mendalam, peneliti menemukan enam tema strategi yang kemudian dikategorikan sebagai strategi internal dan eksternal. Temuan penelitian menunjukkan bahwa Qiscus telah menerapkan enam strategi, yaitu organisasi dengan keterlibatan tinggi, inden (pivot), membangun brand image, mempertahankan pengalaman pengguna, investasi strategis, dan edukasi pasar. Temuan ini mendukung studi sebelumnya bahwa organisasi dengan keterlibatan stakeholder internal yang kuat (high involvement organization) cenderung memiliki kinerja dan produktivitas lebih baik.

Kata kunci: high involvement; ketidakpastian; pivot; startup; strategi

Pada tahun 2013, Bank Dunia menyatakan

${ }^{1}$ Korespondensi mengenai artikel ini dapat dilakukan melalui luqman.perwira@psy.uad.ac.id

2atau smeiyanto@ugm.ac.id bahwa ekonomi digital akan menjadi penopang pertumbuhan ekonomi Indonesia (Hatta, Aryanto \& Syeikh, 2016). Hal ini kini 
kian terbukti melihat semakin besarnya angka transaksi keungan berbasis digital yang tercatat dari tahun ke tahun. Pada tahun 2015, nilai transaksi online yang tercatat menembus angka 3,56 miliar USD, atau setara dengan Rp46 triliun (Indah \& Rizalulhaq, 2017). Pertumbuhan potensi ekonomi digital ini sejalan dengan berkembang pesatnya jumlah pengguna internet di Indonesia. Berdasarkan hasil survey yang dilakukan oleh Asosiasi Penyelenggara Jasa Internet Indonesia (APJII) pada tahun 2016, warga Indonesia yang telah mengakses internet mencapai jumlah 97 juta jiwa dan 60 juta diantaranya telah terbiasa menggunakan internet sebagai tepat berbelanja secara online. Angka tersebut menempatkan Indonesia menjadi negara dengan jumlah pengguna internet terbesar kedua di dunia (APJII, 2016).

Meningkatnya peran internet dan teknologi informasi ini disambut baik oleh para pelaku usaha. Perusahaan rintisan berbasis digital (tech-startup) tumbuh menjamur bak cendawan di musim hujan. Sebagai ilustrasi, pada tahun 2011, idEA atau Asosisasi E-commerce Indonesia di Indonesia hanya beranggotakan sembilan perusahaan. Pada kongres tahun 2017 yang lalu, atau hanya dalam kurun waktu enam tahun, jumlah anggota idEA sudah berlipat menjadi 198 perusahaan (Indah \& Rizalulhaq, 2017). Jumlah tersebut baru merupakan gabungan dari perusahaan startup berbasis e-commerce atau toko online saja, sementara masih terdapat ratusan perusahaan rintisan lain dengan berbagai bidang, seperti transportasi, kuliner, keuangan, dan bahkan pertanian. Gayung bersambut, pemerintah melihat peluang berkembangnya ekonomi digital ini dan meresponnya dengan baik. Kementerian Komunikasi dan Informatika bekerja sama dengan perusahaan incubator startup mencanangkan gerakan 1000 Startup Digital yang menargetkan terbentuknya 1000 perusahaan startup digital baru pada tahun 2020.

Perkembangan yang sangat cepat dalam dunia teknologi khususnya teknologi informasi dan komunikasi menjadi peluang sekaligus tantangan bagi para pegiat startup digital. Perkembangan teknologi tersebut di satu sisi merupakan sarana yang dapat mereka manfaatkan untuk melakukan inovasi dan menghasilkan sebuah produk atau layanan, namun di sisi lain, perkembangan teknologi yang cepat membuat produk mereka dapat seketika menjadi usang atau tidak diperlukan lagi. Hal ini menuntut para pendiri startup untuk terus melakukan inovasi.

Penelitian mengenai perusahaan startup yang ditinjau dari sudut pandang psikologi industri dan organisasi belum banyak dilakukan di Indonesia. Penelitian mengenai perusahaan startup bidang teknologi umumnya mengkaji perusahaan ini dalam kerangka model bisnis yang mereka jalankan. Seperti penelitian yang dilakukan oleh Sitepu (2017) yang menemukan bahwa manajemen internal seperti marketing dan pengelolaan keuangan sangat berpengaruh pada keberhasilan perusahaan startup untuk dapat bertahan.

Sementara di luar negeri, penelitian dengan subjek perusahaan startup digital banyak dilakukan namun dengan sudut pandang ekonomi dan manajemen, di antaranya penelitian yang dilakukan oleh Čalopa, Horvat, dan Lalić (2014), Salamzadeh dan Kesim (2015), dan Salamzadeh dan Kirby (2017). Ketiga penelitian tersebut lebih berfokus pada bagaimana perusahaan startup berkembang ditinjau dari perkembangan pendanaan yang diperoleh. Perbedaan utama dari 
penelitian ini dibanding penelitian yang telah ada sebelumnya adalah terletak pada fokus penelitian yaitu pada tinjauan bagaimana perusahaan startup bertahan di tengah lingkungan bisnis dengan tingkat ketidakpastian yang tinggi (uncertainty). Selain itu, perbedaan penelitian ini terletak pada inovasi yang ditinjau secara spesifik pada perusahaan startup dengan segala karakteristik khas yang dimiliki perusahaan tersebut.

Qiscus Pte Ltd. (Qiscus) merupakan sebuah perusahaan yang bergerak di bidang pembuatan chat engine. Perusahaan ini didirikan pada tahun 2013 oleh empat orang mahasiswa Nanyang Technological University (NTU) yang berasal dari Indonesia dan Singapura. Pada mulanya, perusahaan ini berdiri dengan membuat produk berupa platform media pembelajaran yang digunakan di bidang pendidikan sebelum akhirnya berkembang menjadi perusahaan startup digital penyedia platform diskusi, chatting, dan video call. Perusahaan ini mendapatkan investment besar pertamanya yaitu sebesar 100.000 USD pada tahun 2014 dan menggunakannya untuk mengembangkan instant messenger berbasis iOS maupun Android yang digunakan oleh end user. Kesulitan menemukan pasar untuk menjual produknya, pada tahun 2016 Qiscus mengubah strategi bisnisnya menjadi penjual engine chat yang mendukung platform klien yang telah ada. Target konsumennya berubah dari business to customer menjadi business to business. Strategi ini membuahkan hasil, produk Qiscus banyak dilirik berbagai perusahaan dan akhirnya mendapatkan kepercayaan dari investor untuk mengembangkan Qiscus di akhir tahun 2016 dan hingga saat ini.

Bermain di sektor ini, Qiscus menghadapi banyak kompetitor global, di antaranya adalah Slack, Hipchat, dan Campfire. Ketiga startup tersebut memiliki produk yang relatif serupa dengan produk yang dikeluarkan oleh Qiscus. Belum lagi dengan semakin berkembangnya fitur-fitur yang disediakan oleh aplikasi chatting popular seperti Whatsapp, Telegram, Line, dan BBM. Aplikasi-aplikasi tersebut secara perlahan berkembang menjadi kompetitor tidak langsung bagi Qiscus. Kesulitan menjual produk ini membuat para pendiri Qiscus harus menyusun strategi lain unuk dapat mempertahankan perusahaan. Akhirnya pada tahun 2014, para founder membagi dua unit kerja dalam perusahaan. Unit pertama tetap berfokus pada pengembangan platform yang telah menjadi produk utama mereka, sementara unit yang lain mengembangkan produk berdasarkan permintaan dari klien. Strategi ini dilakukan agar perusahaan tetap mendapatkkan pemasukan untuk dapat bertahan.

Tahun 2015 merupakan tahun yang sulit bagi banyak startup. Pada tahun ini, banyak perusahaan startup yang gulung tikar dikarenakan para investor mulai selektif dalam menanamkan modalnya. Pertumbuhan tidak menjadi satu-satunya pertimbangan investor untuk berinvestasi. Akibatnya, perusahaan-perusahaan rintisan yang tidak memiliki model bisnis yang bagus mulai kehabisan dana dan akhirnya tutup. Tak terkecuali Qiscus, startup ini mulai kehabisan dana dari para investor serta kesulitan mengembangkan dan menjual produknya. Akhirnya pada pada akhir tahun 2015, Qiscus berinovasi untuk membuat aplikasi chat pada platform startup lain. Peluang ini dapat dimanfaatkan dengan baik hingga membuat Qiscus mengubah strategi pemasarannya dari memproduksi aplikasi yang digunakan oleh end user menjadi chat engine yang digunakan 
pada platform lain. Model bisnis berubah dari B2C (business to customer) menjadi B2B (business to business). Qiscus melakukan inovasi pada produk dan strateginya untuk dapat bertahan dan selanjutnya mendapatkan kepercayaan investor untuk menanamkan modalnya di Qiscus.

Bergerak di bidang teknologi informasi, Qiscus harus menghadapi lingkungan bisnis dengan kecepatan perubahan yang tinggi. Iklim binis ini tergolong iklim bisnis dengan tingkat ketidakpastian yang tinggi mengingat segala sesuatunya dapat berubah hanya dalam hitungan hari. Sebagaimana yang terungkap dari wawancara pendahuluan yang dilakukan peneliti kepada salah seorang pendiri perusahaan Qiscus yang kini menjabat sebagai Chief Technology Officer (CTO) :

"Ya, tapi ini kompetisi di bidang kita ini kadang jauh lebih riskan sih. Ketika nanti ada suatu player baru, misalnya Google tiba-tiba bikin fitur chat system, kita kan harus offering yang lain. maksudnya ngalahin Google di bidang ini kan susah biasanya mereka udah superior technology, price-nya pasti murah, nah itu gawat. Jadinya harus punya offering yang lain yang bisa kita tawarkan. (W1 S1 823-827)

Fenomena di atas menarik perhatian peneliti untuk melihat lebih dekat bagaimana sebuah perusahaan startup menjaga eksistensinya di tengah situasi dengan kompleksitas dan ketidakpastian yang tinggi melalui berbagai strategi yang dikembangkan. Peneliti ingin mengetahui bagaimana sebuah perusahaan startup yang berhasil survive dan berkembang menyikapi tantangan yang dihadapi berupa lingkungan bisnis dengan ketidakpastian yang tinggi.
Qiscus terbukti mampu melewati masa-masa sulit bagi perusahaan startup di tahun 2015 dan berhasil mengubah strategi bisnis dan fokus produknya hingga dapat bertahan. Melalui penelitian ini peneliti ingin menjawab pertanyaan: Apa strategi Qiscus untuk dapat mencapai keunggulan kompetitif dalam situasi ketidakpastian lingkungan bisnis yang tinggi? Bagaimana dinamika penerapan strategi tersebut? Melalui pendekatan studi kasus, pertanyaan-pertanyaan tersebut akan dicoba untuk dijawab melalui penelitian ini.

\section{Metode}

Studi mengenai inovasi di perusaahan startup ini dilakukan dengen pendekatan kualitatif karena peneliti memiliki tujuan utama untuk memahami dan mengeksplorasi dinamika dan proses inovasi serta faktor-faktor pengiring lain yang membuat sebuah perusahaan startup digital dapat unggul dan berkembang dibanding dengan perusahaan rintisan lain. Pendekatan kualitatif dengan metode case study menjadi strategi penelitian yang lebih tepat untuk memenuhi tujuan penelitian tersebut.

Subjek dalam penelitian ini adalah Perusahaan Startup Digital PT Qiscus Ltd sebagai sebuah entitas bisnis. Qiscus dipilih sebagai subjek berdasarkan kesesuaiannya dengan fenomena yang akan dikaji yaitu perusahaan rintisan yang mampu bertahan di tengah ketidakpastian lingkungan bisnis. Bertindak sebagai sumber data adalah anggota organisasi yang terdiri dari dua kategori besar, yaitu founder dan member (karyawan).

Penentuan founder dan karyawan sebagai sumber data didasarkan atas pengertian umum organisasi yang 
merupakan sebuah entitas sosial yang berinteraksi secara sadar untuk mencapai tujuan tertentu (Robbins \& Barwell, 2002). Entitas sosial yang saling berinteraksi tersebut diantaranya adalah pemiliki bisnis, manajer, dan karyawan. Dalam konteks penelitian ini, pemilik bisnis (founder) bertindak sebagai pimpinan perusahaan, sehingga hanya ada dua entitas sosial yaitu pemiliki bisnis dan karyawan. Data dalam penelitian ini diambil dari proses wawancara yang dilakukan kepada dua (2) orang founder dan enam (6) orang staf Qiscus yang paling awal bergabung dengan perusahaan ini.

Seluruh narasumber merupakan karyawan yang tergolong karyawan paling awal bergabung dengan Qiscus. Pemilihan narasumber ini dilakukan atas pertimbangan kekayaan informasi yang dimiliki oleh karyawan dengan masa kerja paling lama. Data-data yang diperoleh diharapkan dapat lebih lengkap dan mendalam karena karyawan-karyawan tersebut telah mengalami pasang surut perjalanan Qiscus. Dua orang narasumber yaitu narasumber 7 dan 8 merupakan dua orang pendiri Qiscus.

Tabel 1.

Prosedur Analisis Data
Keduanya merupakan rekan satu kampus ketika menempuh pendidikan di Nanyang Technological University, Singapura. Beserta dua orang rekannya, kedua mahasiswa ini merintis sebuah platform pembelajaran yang akhirnya berkembang menjadi aplikasi chat. Narasumber 7 bertindak sebagai Chief Technological Officer (CTO) sementara Narasumber 8 merupakan CEO dari perusahaan ini.

Peneliti menggunakan wawancara serta obsvasi sebagai metode pengambilan data utama. Selain itu, peneliti juga menggunakan sumber informasi lain seperti dokumen perusahaan yang tersaji secara online dalam website, artikel berita, dan pengamatan langsung terhadap artefak fisik perusahaan.

Dalam analisis dan interpretasi data, seluruh metode penelitian kualitatif memiliki prosedur dasar yang hampir sama yaitu menganalisis data yang terkumpul, mengelompokkannya ke dalam beberapa tema atau perspektif, dan melaporkan empat sampai 5 tema (Patton, 2002 ; Creswell, 2009) Secara lebih spesifik, prosedur analisis data yang akan dilakukan diuraikan seperti yang terlihat pada Tabel 1.

\begin{tabular}{|c|c|c|c|}
\hline No. & Prosedur Analisis Data & Proses & Hasil \\
\hline 1. & Open Coding & $\begin{array}{l}\text { - Peneliti memberikan catatan-catatan (kode) } \\
\text { pada transkrip hasil wawancara serta } \\
\text { observasi pada informasi yang dapat } \\
\text { memberikan jawaban pada pertanyaan } \\
\text { penelitian } \\
\text { - Peneliti memberikan label berupa tema } \\
\text { yang mampu mencakup kode-kode dengan } \\
\text { dengan kesamaan isi. }\end{array}$ & $\begin{array}{l}\text { - Open Coding Masing- } \\
\text { masing narasumber } \\
\text { - Label berupa tema- } \\
\text { tema. }\end{array}$ \\
\hline 2. & Axial Coding & $\begin{array}{l}\text { - Peneliti menggabungkan catatan-catatan } \\
\text { yang sama dari setiap narasumber dan } \\
\text { dikelompokkan menjadi satu. } \\
\text { - Peneliti menyusun rangkaian hubungan } \\
\text { antar tema }\end{array}$ & $\begin{array}{l}\text { - Kumpulan tema yang } \\
\text { dihimpun dari seluruh } \\
\text { narasumber } \\
\text { - Dinamika hubungan } \\
\text { antar tema }\end{array}$ \\
\hline
\end{tabular}


Pada tahap open coding, peneliti membuat kategori tertentu terhadap hasil wawancara. Dalam setap kategori, data dipilah menjadi sub kategori kemudian dicari adanya rangkaian hubungan dari sub kategori. Pada tahap axial coding, peneliti menyatukan berbagai data dengan istilah baru yang menggambarkan berbagai kategori. Pada tahap ini pula, peneliti mengembangkan sebuah rangkaian dinamika yang menggambarkan hubungan antar tiap kategori hingga membentuk suatu kerangka atau model (Strauss \& Corbin, 1990).

Kredibilitas penelitian ini dijaga dengan menerapkan prinsip-prinsip triangulasi yang dilakukan dalam penelitian kualitatif. Patton (2002) menyatakan bahwa triangulasi dilakukan dengan empat cara, yaitu: 1) triangulasi data, 2) triangulasi antar evaluator, 3) triangulasi teori, dan 4) triangulasi metode. Pada penelitian ini, triangulasi dilakukan dengan melakukan verifikasi data melalui sumber lain untuk memastikan bahwa data tersebut kredibel (Yin, 2012). Untuk meningkatkan kredibiltas penelitian ini, peneliti juga akan melakukan penggambaran yang komprehensif dan mendalam (rich and thick description) untuk memberikan cukup informasi bagi pembaca untuk dapat melakukan penilaian (Creswell, 2009). Peneliti juga melakukan member checking (Creswell, 2009) atau validasi responden (Birt, Scott, Cavers, Campbell, \& Walter, 2016) untuk memastikan temuan penelitian berupa tema dan dinamika dapat diterima oleh narasumber.

\section{H a s i 1}

\section{Profil Qiscus}

Qiscus merupakan perusahaan berstatus Perseroan Terbatas dengan pendiri Sdr. DP sebagai Direktur dan Sdr. EP sebagai
Komisarisnya. Qiscus berdiri di Singapura tahun 2013 setelah memenangkan kompetisi startup yang diselenggarakan oleh Kementerian Pendidikan Pemerintah Singapura. Pada mulanya, Qiscus bergerak di bidang teknologi pembelajaran dengan mengembangkan sebuah platform sistem pembelajaran digital. Pada bulan Juli tahun 2013, Qiscus akhirnya bertransformasi menjadi perusahaan rintisan teknologi yang menjadi penyedia aplikasi chat \& chat engine.

Qiscus mendapatkan pendanaan pertamanya pada bulan Desember tahun 2014 sebesar 100.000 SGD yang berasal dari perusahaan SPAZE yakni perusahaan venture capital yang berbasis di Singapura. Qiscus nyaris bangkrut karena calon investor membatalkan investasinya pada pertengahan 2015, Qiscus mendapatkan kepercayaan investor kembali pada bulan Desember tahun 2015 sebanyak 375.000 SGD. Investasi ini berasal dari perusahaan MHealth dan Doku, dua perusahaan yang berbasis di Indonesia. Pada Bulan Januari 2017, Qiscus kembali mendapatkan pendanaan dari kedua perusahaan tersebut ditambah dengan PT Telkom dengan total investasi sebesar 300.000 SGD.

Model bisnis Qiscus saat ini adalah menjual chat engine yang digunakan oleh perusahan-perusahan berbasis teknologi untuk mendukung kebutuhan komunikasi real time dalam platform mereka. Terdapat dua produk Qiscus yaitu paket Software Development Kit (SDK) dan End to End Solution. Matriks kunci yang dapat digunakan untuk mengukur keberhasilan model bisnis Qiscus saat ini adalah jumlah perusahaan yang menjadi klien dan jumlah pengguna (user). Saat ini, jumlah pengguna yang menggunakan produk chatting Qiscus mencapai lebih dari satu juta. Pendapatan (revenue) dari bisnis Qiscus saat ini mencapai 
300.000 USD atau sekitar 3 miliar rupiah per tahun.

Qiscus saat ini mempekerjakan empat puluh satu (41) orang karyawan. Diantara seluruh karyawan yang masih aktif bekerja sampai saat ini, karyawan yang paling awal bergabung adalah AJ yang mulai bergabung sejak 16 September 2014. Karyawan terbaru baru bergabung 19 Desember 2017. Seluruh karyawan berkantor di Yogyakarta, sementara salah seorang founder berada di kantor Jakarta.

\section{Strategi Qiscus}

Data-data yang diperoleh melalui proses wawancara yang dilakukan kepada seluruh narasumber selanjutnya diklasifikasikan dan dikategorikan ke dalam beberapa tema dan sub tema. Temuan tema dan sub tema dapat dilihat pada Tabel 2 (lihat halaman 104).

Situasi ketidakpastian yang dialami Qiscus, baik berupa ketidakpastian modal, pesaing, maupun pasar, menuntut Qiscus untuk mampu memberikan respons yang tepat untuk dapat bertahan dalam bisnis ini. Terdapat enam strategi utama yang dilakukan oleh Qiscus dalam menghadapi tantangan eksternal tersebut. Keenam strategi tersebut dibagi ke dalam dua kategori besar yaitu strategi internal dan strategi eksternal. Dinamika strategi Qiscus dapat dilihat dalam Gambar 1 .

Strategi internal menggambarkan strategi yang diarahkan ke dalam organisasi dan melibatkan unsur-unsur sistem internal organisasi meliputi majemen SDM, struktur, dan model bisnis. Strategi internal ini terbagi ke dalam tiga strategi yaitu high involvement organization, pivot, dan membangun brand image. Strategi eksternal menggambarkan strategi yang diarahkan kepada pihak di luar organisasi seperti konsumen, masyarakat teknologi, dan investor. Strategi eksternal terdiri dari tiga strategi yaitu maintaining user experience, pendanaan strategis, dan edukasi pasar.

\section{Strategi internal}

Soliditas internal perusahaan yang terbangun melalui high involvement organization memastikan Qiscus mampu menghadapi perubahan-perubahan yang terjadi, baik perubahan dari dalam maupun perubahan situasi bisnis. Strategi High Involvement ini diwujudkan dengan meningkatkan keterlibatan dan partisipasi seluruh stakeholder perusahaan. Strategi ini membuat para karyawan memahami situasi bisnis yang dihadap oleh Qiscus, sehingga mereka mampu terlibat aktif dan mau berjuang bersama dengan perusahaan.

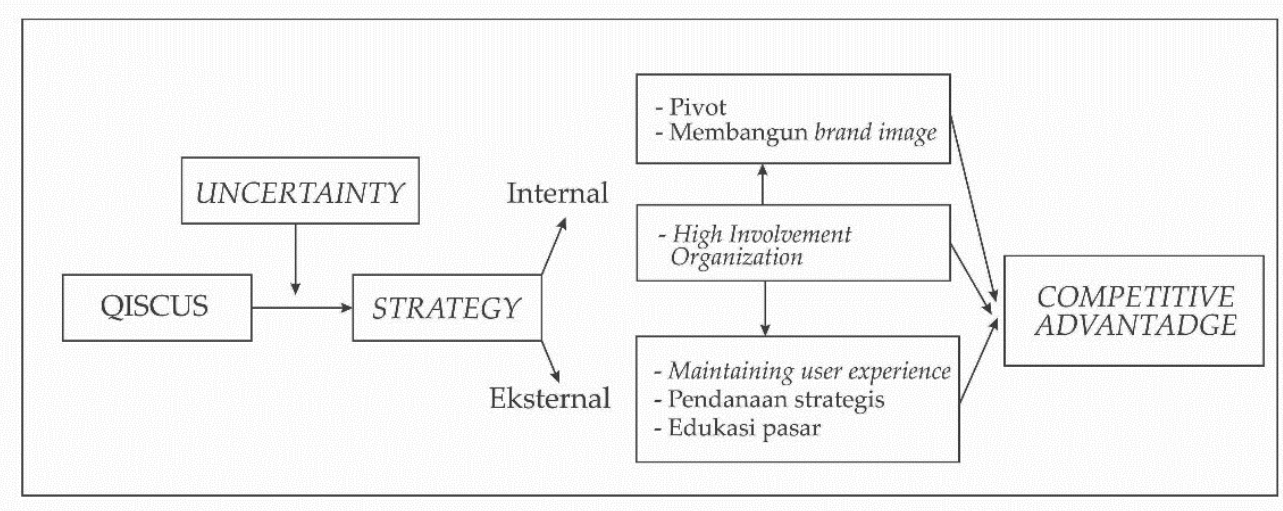

Gambar 1. Skema dinamika strategi Qiscus 
Tabel 2.

Temuan Tema Utama

\begin{tabular}{|c|c|c|c|}
\hline Tema & Makna & Subtema & Bentuk Perilaku \\
\hline \multirow[t]{7}{*}{ Pivot } & \multirow{7}{*}{$\begin{array}{l}\text { Perubahan model } \\
\text { bisnis yang diikuti } \\
\text { dengan perubahan } \\
\text { komponen organisasi } \\
\text { yang lain }\end{array}$} & $\begin{array}{l}\text { Berganti model } \\
\text { bisnis/produk }\end{array}$ & $\begin{array}{l}\text { Mengubah produk yang dijual } \\
\text { dari aplikasi chat menjadi chat } \\
\text { engine }\end{array}$ \\
\hline & & $\begin{array}{l}\text { Melakukan inovasi pada } \\
\text { produk }\end{array}$ & $\begin{array}{l}\text { Memberikan tambahan- } \\
\text { tambahan fitur pada produk }\end{array}$ \\
\hline & & Meng-upgrade teknologi & $\begin{array}{l}\text { Meningkatkan kualitas website } \\
\text { dan menambah kapasitas server }\end{array}$ \\
\hline & & Meng-upgrade struktur & Menambahkan divisi marketing \\
\hline & & $\begin{array}{l}\text { Karyawan siap berubah } \\
\text { skill dan posisi }\end{array}$ & $\begin{array}{l}\text { Setiap karyawan dapat } \\
\text { ditempatkan diposisi yang } \\
\text { berbeda sewaktu-waktu }\end{array}$ \\
\hline & & Belajar dari kegagalan & $\begin{array}{l}\text { Menjadikan pengalaman } \\
\text { kegagalan mendapatkan } \\
\text { investasi sebagai pelajaran untuk } \\
\text { mengambil langkah berikutnya }\end{array}$ \\
\hline & & $\begin{array}{l}\text { Evaluasi proyeksi dan } \\
\text { strategi } 3 \text { bulanan }\end{array}$ & $\begin{array}{l}\text { Mengubah strategi dan target } \\
\text { pencapaian apabila dinilai tidak } \\
\text { memungkinkan }\end{array}$ \\
\hline \multirow{5}{*}{$\begin{array}{l}\text { Maintaining } \\
\text { User } \\
\text { Experience }\end{array}$} & \multirow{5}{*}{$\begin{array}{l}\text { Mempertahankan } \\
\text { pelanggan dengan } \\
\text { menjaga kepuasan } \\
\text { pelanggan dalam } \\
\text { menggunakan } \\
\text { produk dan layanan }\end{array}$} & $\begin{array}{l}\text { Mempertahankan standar } \\
\text { pelayanan }\end{array}$ & $\begin{array}{l}\text { Terdapat standar minimum } \\
\text { pelayanan yang harus terpenuhi }\end{array}$ \\
\hline & & $\begin{array}{l}\text { Meng-upgrade teknologi } \\
\text { untuk pelanggan }\end{array}$ & $\begin{array}{l}\text { Meningkatkan kapasitas server } \\
\text { dan meng-upgrade website }\end{array}$ \\
\hline & & $\begin{array}{l}\text { Mendengar feedback dari } \\
\text { klien }\end{array}$ & $\begin{array}{l}\text { Membahas evaluasi klien dalam } \\
\text { rapat }\end{array}$ \\
\hline & & $\begin{array}{l}\text { Menjaga kepuasan } \\
\text { pelanggan }\end{array}$ & $\begin{array}{l}\text { Menjaga hubungan baik dengan } \\
\text { klien }\end{array}$ \\
\hline & & $\begin{array}{l}\text { Benchmarking untuk } \\
\text { meningkatkan pelayanan }\end{array}$ & Meneliti produk kompetitor \\
\hline \multirow[t]{3}{*}{ Edukasi Pasar } & \multirow{3}{*}{$\begin{array}{l}\text { Memperluas pasar } \\
\text { dengan } \\
\text { meningkatkan } \\
\text { pemahaman calon } \\
\text { user mengenai } \\
\text { produk Qiscus }\end{array}$} & $\begin{array}{l}\text { Meningkatkan } \\
\text { pemahaman calon } \text { user }\end{array}$ & $\begin{array}{l}\text { Mengedukasi bahwa membuat } \\
\text { chat mahal dan membutuhkan } \\
\text { banyak resources }\end{array}$ \\
\hline & & Memperluas pasar & $\begin{array}{l}\text { Membuka link dengan berbagai } \\
\text { instansi }\end{array}$ \\
\hline & & $\begin{array}{l}\text { Techtalk sebagai sarana } \\
\text { edukasi pasar }\end{array}$ & $\begin{array}{l}\text { Sosialisasi kemampuan dan } \\
\text { teknologi Qiscus di techtalk }\end{array}$ \\
\hline \multirow[t]{3}{*}{$\begin{array}{l}\text { Pendanaan } \\
\text { Strategis }\end{array}$} & \multirow{3}{*}{$\begin{array}{l}\text { Pendanaan } \\
\text { mempertimbangkan } \\
\text { prospek } \\
\text { pengembangan } \\
\text { perusahaan ke depan }\end{array}$} & Strategi menarik investor & $\begin{array}{l}\text { Menunjukkan kemampuan } \\
\text { Qiscus dalam meraih profit }\end{array}$ \\
\hline & & Manajemen pendanaan & $\begin{array}{l}\text { Pertimbangan strategis dalam } \\
\text { menentukan nama dan jumlah } \\
\text { investor yang didekati }\end{array}$ \\
\hline & & Manajemen risiko & $\begin{array}{l}\text { Melakukan perhitungan ketat } \\
\text { terhadap pengeluaran } \\
\text { mempertimbangkan }\end{array}$ \\
\hline
\end{tabular}




\begin{tabular}{|c|c|c|c|}
\hline & & & $\begin{array}{l}\text { ketersediaan investor di masa } \\
\text { depan }\end{array}$ \\
\hline & & Upaya mandiri & $\begin{array}{l}\text { Berusaha untuk tidak } \\
\text { menggantungkan diri pada } \\
\text { investor }\end{array}$ \\
\hline \multirow[t]{6}{*}{$\begin{array}{l}\text { High } \\
\text { Involvement } \\
\text { Organization }\end{array}$} & \multirow[t]{6}{*}{$\begin{array}{l}\text { Keterlibatan stake } \\
\text { holder yang tinggi } \\
\text { dalam }\end{array}$} & Memberikan konteks & $\begin{array}{l}\text { Memberitahukan kondisi terkini } \\
\text { perusahaan dan bagaimana } \\
\text { situasi bisnis } 3 \text { bulan ke depan }\end{array}$ \\
\hline & & $\begin{array}{l}\text { Membangun hubungan } \\
\text { baik }\end{array}$ & $\begin{array}{l}\text { Founder memberikan personal } \\
\text { touch kepada masing-masing } \\
\text { karyawan }\end{array}$ \\
\hline & & $\begin{array}{l}\text { Komunikasi intensif dua } \\
\text { arah }\end{array}$ & $\begin{array}{l}\text { Menyediakan sesi one to one } \\
\text { dengan founder }\end{array}$ \\
\hline & & $\begin{array}{l}\text { Memberikan } \\
\text { kenyamanan pada } \\
\text { karyawan }\end{array}$ & $\begin{array}{l}\text { Menyiapkan petugas khusus } \\
\text { untuk memastikan karyawan } \\
\text { merasa nyaman di kantor }\end{array}$ \\
\hline & & $\begin{array}{l}\text { Membangun komitmen } \\
\text { karyawan }\end{array}$ & $\begin{array}{l}\text { Melakukan pendekatan dengan } \\
\text { memberikan personal touch } \\
\text { kepada seluruh karyawan }\end{array}$ \\
\hline & & $\begin{array}{l}\text { Membangun soliditas } \\
\text { tim/dampak dari } \\
\text { engangement jadi solid }\end{array}$ & $\begin{array}{l}\text { Menyelenggarakan storytelling, } \\
\text { dan English Day }\end{array}$ \\
\hline \multirow[t]{4}{*}{$\begin{array}{l}\text { Membangu } n \\
\text { Brand Image }\end{array}$} & \multirow{4}{*}{$\begin{array}{l}\text { Upaya untuk terus } \\
\text { fokus dan menerus } \\
\text { membangun } \\
\text { keahlian di } \\
\text { bidangnya }\end{array}$} & $\begin{array}{l}\text { Branding sebagai ahli } \\
\text { komunikasi }\end{array}$ & Menyelenggarakan techtalk \\
\hline & & $\begin{array}{l}\text { Berproses untuk } \\
\text { membangun keahlian }\end{array}$ & $\begin{array}{l}\text { Mengerjakan proyek dari klien } \\
\text { dengan terus- menerus } \\
\text { memperbaiki kuaitas produk }\end{array}$ \\
\hline & & $\begin{array}{l}\text { Techtalk sebagai sarana } \\
\text { branding }\end{array}$ & $\begin{array}{l}\text { Menyelenggarakan techtalk } \\
\text { secara rutin dan konsisten }\end{array}$ \\
\hline & & $\begin{array}{l}\text { Fokus pada kekuatan } \\
\text { yang dibangun }\end{array}$ & $\begin{array}{l}\text { Konsisten hanya mengerjakan } \\
\text { sesuatu yang masih } \\
\text { berhubungan dengan chat dan } \\
\text { komunikasi }\end{array}$ \\
\hline
\end{tabular}

Perwujudan dari strategi ini adalah berupa pemberian konteks kepada para karyawan. Konteks ini merupakan upaya untuk membuka pemahaman karyawan terhadap situasi dan tantangan yang dihadapi Qiscus.

"Founder menurut saya melakukan fasilitasi meyakinkan kita mampu, karyawan juga diharapkan memahami kondisinya seperti itu, terus ngasih apa ya, sesuatu yang lebih buat perusahaan buat mencapai tujuan itu, saya rasa sih seperti itu trus mau ngasih lebih ke perusahaan untuk mencapai tujuan itu" (W1, N4)

Dengan memberikan konteks ini, founder bermaksud untuk memberikan makna kepada para karyawan agar mereka tidak hanya mengerjakan apa yang menjadi kewajiban mereka namun tahu apa gambaran besar dan manfaat dari pekerjaan yang sedang ia kerjakan bagi dirinya dan perusahaan. 
Langkah ini terbukti menjadikan karyawan Qiscus merasa engaged atau merasa menjadi bagian penting dari perusahaan. Dengan hal tersebut, karyawan menyadari bahwa kinerjanya akan berdampak besar pada keseluruhan kinerja organisasi.

"Qiscus bisa bertahan sampai sejauh ini salah satunya karena bagaimana para founder ini mereka bisa meyakinkan karyawannya menganggap karyawannya itu sebagai ya, istilahnya kayak keluarga, semua yang dari perusahaan diupdate ke karyawan menganggap itu sebagai partner itu menurut saya salah satu kunci suksesnya" (N4)

Hal ini menimbulkan konsekuensi karyawan menjadi memiliki kepedulian terhadap situasi bisnis yang dihadapi yaitu berkaitan dengan peluang, masalah, hingga pesaing langsung yang dihadapi. Kesadaran karyawan ini pada akhirnya memberikan batu pijakan bagi organisasi untuk melakukan manuver-manuver atau perubahan-perubahan dalam merespon situasi termasuk di antara perubahan model bisnis (pivot). Soliditas internal ini memudahkan organisasi untuk mampu bertahan dan mencapai keunggulan kompetitif.

Strategi Qiscus berikutnya yakni pivot, dapat diartikan sebagai upaya founder untuk mengubah model bisnis perusahaan. Strategi ini menggambarkan perubahan mendasar pada model bisnis yang dijalani oleh Qiscus. Perubahan ini secara otomatis diikuti dengan perubahan komponen organisasi yang lain, diantaranya adalah strategi bisnis, struktur, produk dan teknologi. Qiscus telah melakukan pivot sebanyak tiga kali sampai akhirnya menemukan model bisnis saat ini yang mampu perlahan mendatangkan keuntungan dan kepercayaan investor.

"Dari situ sampai sekarang produk kita pivot. Kita pengen satu yang bisa lebih banyak yang bisa pake, bukan aplikasi messaging lagi, di mana itu marketnya kita bisa men-support startup-startup yang punya fitur ga jauh jauh dari chat engine. Kita bisa masuk itu peluangnya lebih besar dan memang terbukti setelah pivot kita fokus ke chat engine-nya lumayan banyak startup klien kita" (W1, N4)

Qiscus berusaha menjaga keseimbangan antara perubahan model bisnis dengan fokus bisnis yang dikembangkan. Semenjak awal berdirinya, Qiscus masih tetap bergerak pada jalur yang sama yaitu sebagai penyedia layanan real time communication berbasis chat. Meskipun sempat mengalami perubahan model bisnis hingga beberapa kali, Qiscus tidak pernah beralih dari teknologi chat. Langkah ini merupakan langkah strategis yang sengaja diambil oleh Qiscus untuk mendapatkan tempat dalam peta persaingan perusahaan startup digital di Indonesia.

“Fokus sama bisnisnya Qiscus itu saya rasa itu yang membuat Qiscus bertahan sampai saat ini mungkin, fokus hanya dengan itu, yakin kalau apa yang dilakukan itu valid, udah ada data data. Tidak menyerahkan dengan istilahnya kita garap dengan sesuatu yang yakin hanya dengan keyakinan aja. Kalau sekarang dengan data" (W1, N4) 
Fokus tersebut membuat Qiscus memiliki keahlian spesifik yang terus didalami dan akhirnya menjadi trade mark perusahaan. Melalui kepekaan bisnisnya (business awareness), para founder berkeyakinan bahwa dunia chat dan komunikasi masih memiliki masa depan yang sangat cerah dalam perkembangan teknologi ke depan. Atas dasar keyakinan ini, strategi berikutnya yang dikembangkan oleh Qiscus adalah dengan membangun keahlian (building expertise) di bidang komunikasi dengan spesifikasi penyedia chat engine. Pengalaman menempa Qiscus untuk membangun keahlian dalam bidang ini, sebagaimana yang dinyatakan oleh salah seorang narasumber sebagai berikut.

"Ketemu core-nya masih di chatting, itu sudah jadi expertise kita. Kita udah 5 tahun ngerjain ini doang. Angle-nya aja yang beda, packaging-nya dan target market yang berbeda. Dari dulu kita gitu sih. Semua event-nya pasti ada urusannya ama chatting. Sesuatu yang makin lama jadi privilege kita. Udah lama, banyak, 5 tahun, kita ngerjain ini doang. Tapi dengan angle yang berbeda-beda. (W1, N2).

Proses membangun keahlian ini juga diiringi dengan kesadaran untuk membangun brand perusahaan. Qiscus memanfaatkan sarana berbagi perkembangan teknologi yang dimilikinya yaitu techtalk sebagai ajang untuk memperkuat posisi Qiscus sebagai leading player di bidang chat dan komunikasi. Atas upaya ini, banyak perusahaan teknologi rintisan baru (tech startup) maupun perusahaan konvensional yang telah mapan dapat tertarik menjadi klien Qiscus. Melalui klien-klien ini, setahap demi setahap Qiscus mampu menemukan model bisnis terbaiknya dan mulai memperoleh kepercayaan dari investor. Lebih jauh, situasi ini positif ini mampu membuat Qiscus dapat mengumpulkan revenue yang cukup untuk menjalankan roda bisnis perusahaan.

\section{Strategi eksternal}

Strategi eksternal perusahaan dilakukan dengan tiga pendekatan yaitu maintaining user experience, edukasi pasar, dan pendanaan strategis. Ketiga tema ini mewakili upaya perusahaan untuk mempertahankan pengguna, melebarkan jangkauan pasar serta mengembangkan perusahaan melalui pendanaan. Qiscus menyadari untuk dapat bertahan dan mencapai keunggulan kompetitif serta mendapatkan kepercayaan dari investor, sebuah perusahaan startup harus memiliki nilai jual yang tinggi dengan memiliki matriks yang positif. Matriks bisnis yang dipilih oleh Qiscus adalah dengan menghasilkan uang (monetize) dari jumlah pengguna produknya. Untuk itu, Qiscus berupaya untuk terus menerus menambah jumlah perusahaan pengguna jasanya melalui berbagai strategi.

Langkah menambah jumlah pengguna ini harus diawali dengan upaya untuk menjaga kualitas pelayanan atau dapat disebut dengan user experience. Bertahannya pelanggan lama karena meningkatnya user experience akan menjadi dasar langkah berikutnya yaitu melakukan ekspansi melalui edukasi pasar.

“Tantangan yang lain adalah bagaimana kita bisa mengedukasi market, mungkin itu sih, dari awal itu menjadi challenge yang besar yang pertama sih mungkin ya ngasih tau ini 
bikin chat itu mahal, dan juga bagaimana sebenarnya user atau usernya mereka yang mereka pengen bantu dengan chat itu punya ekspektasi tinggi banget, jadi di sisi user, kalau bikin sendiri itu ribet dan sebenarnya itu bukan core bisnis mereka (W1, N2)

Melalui strategi maintaining user experience dan edukasi pasar, Qiscus perlahan-lahan membangun model bisnis yang semakin mapan dengan berfokus pada penjualan produk dan perluasan pasar. Model bisnis yang mulai menjanjikan dapat menarik para investor untuk menanamkan modalnya ke perusahaan. Seiring dengan meningkatnya kepercayaan para calon investor ini, Qiscus justru melakukan pertimbangan-pertimbangan strategis untuk menentukan investor. Tidak hanya berfokus pada nominal yang akan ditanamkan, Qiscus juga mempertimbangkan aspek lain seperti peluang pendampingan, akses dan juga kepercayaan publik yang meningkat sebelum memutuskan untuk menjalin kerja sama dengan investor tertentu.

"Setiap ini ada beberapa sih. Kita sih kadang-kadang funding tuh kan bukan karena uang aja ya, misalkan pengen cari mentorship dari corporate. Atau kita pengen masuk ke channel-nya dia karena emang besar, kadang beyond uang. Oke uang emang nambah, tapi kadang lebih ke strategiknya sih."

Selain itu, langkah strategis lain yang diambil adalah dengan menjaga independensi melalui langkah mengatur jumlah perusahaan penyandang dana yang akan terlibat. Hal ini dapat menjadi sarana bagi Qiscus untuk menghindari intervensi yang terlalu kuat dari investor tunggal.

\section{Diskusi}

Qiscus hidup di tengah ketidakpastian lingkungan bisnis yang tinggi. Ketidakpastian ini terdiri dari ketidakpastian masa depan pendanaan, ketidakpastian model bisnis yang dipengaruhi oleh perkembangan teknologi, serta ketidakpastian kompetitor. Qiscus memiliki banyak kompetitor yang bersifat indirect, karena pada dasarnya seluruh platform media sosial yang berbasis chat merupakan kompetitor bagi Qiscus. Kompetitor langsung pun tidak kalah memberikan ancaman, meskipun perusahaan competitor yang bersaing secara head to head berbasis di Amerika Serikat, Qiscus tidak dapat merasa aman dengan hal ini karena jarak konsumen dengan pesaing hanya tinggal satu klik saja. Situasi ini menuntut Qiscus untuk memiliki nilai keunggulan yang dapat terus dikembangkan untuk dapat bersaing dan menjadi pilihan bagi konsumen. Keunggulan kompetitif menjadi sangat penting di tengah persaingan bisnis yang sangat dinamis sebagaimana yang dihadapi oleh Qiscus.

Dalam kajian mengenai strategi manajemen, keunggulan kompetitif diartikan sebagai keunikan posisi suatu organisasi terhadap pesaing. Keunikan atau nilai tambah ini membuat pengguna memilih suatu perusahaan dibanding perusahaan lain (Cater \& Pujko, 2005) Meskipun keunggulan kompetitif sering disamakan dengan tujuan atau performa organisasi, kedua hal ini sebetulnya berbeda (Shannassy, 2008) Semua perusahaan mampu menunjukkan performa, baik positif maupun negatif, namun tidak semua perusahaan memiliki keunggulan kompetitif. 
Dalam situasi bisnis dengan ketidakpastian yang tinggi serta persaingan yang ketat, keunggulan kompetitif harus dimiliki oleh perusahaan yang ingin bertahan dan berkembang. Berbagai strategi dapat digunakan untuk mencapai tujuan ini. Untuk membahas strategi perusahaan yang dikaji dalam penelitian ini, tidak ada salahnya peneliti meminjam teori klasik yang merumuskan strategi-strategi perusahaan untuk mencapai keunggulan kompetitif yang dirumuskan oleh Porter pada tahun 1980 (Dess \& Davis, 1984). Berdasarkan penelitian empiriknya, Porter merumuskan strategi perusahaan ke dalam tiga strategi utama, yaitu leadership cost, differentiation, serta focus.

Ditinjau menggunakan perspektif teoretis di atas, strategi Qiscus untuk meraih keunggulan kompetitif dapat digolongkan ke dalam strategi diferensiasi fokus. Qiscus melakukan diferensiasi dengan menawarkan nilai tambah produknya dibanding dengan yang ditawarkan kompetitor. Upaya diferensiasi juga dapat terlihat melalui proses-proses pivot yang dilakukan oleh Qiscus. Gien pada tahun 2001 (Dess \& Davis, 1984) menyatakan bahwa peningkatan kualitas pelayanan dan produk dapat tergolong juga sebagai strategi diferensiasi.

Selain melakukan diferensiasi, Qiscus juga melakukan strategi focus melalui upayaupayanya melakukan spesifikasi produk. Setelah melakukan pivot dari business to customer ke business to business, Qiscus menyasar ceruk pasar yang lebih sempit yaitu perusahaan rintisan berbasis teknologi. Dari sisi produk, Qiscus juga tetap berfokus pada tema yang sama yaitu instant messeging. Strategi ini membuahkan hasil berupa brand recognition yang cukup kuat di kalangan pelaku usaha startup digital yang berdampak pada bertumbuhnya jumlah klien Qiscus. Branding yang kuat ini dibangun dengan konsistensi produk dan juga media branding berupa forum teknologi yang bernama Techtalk.

Langkah Qiscus ini menguatkan pernyataan Srivasta \& Kamdar (2009) bahwa brand image yang konsisten dapat meningkatkan kekuatan marketing suatu produk. Kekuatan brand image menggambarkan sebarapa cepat suatu brand dikenali oleh konsumen. Kekuatan suatu brand harus ditopang dengan persepsi positif konsumen mengenai brand tersebut agar suatu produk dapat diterima dengan baik (Raj \& Roy, 2015). Brand image yang positif ini dibangun oleh Qiscus dengan strategi berikutnya yaitu menjaga kepuasan pelanggan (user experience) dalam menggunakan produk mereka.

Pengalaman pengguna produk yang positif (positive user experience) secara teoritis maupun empiris berhubungan dengan kepuasan pelanggan terhadap layanan atau produk (Balaji, Arumugham, Cavrak, Knuycky, \& Lutz, 2015). Upaya memuaskan pengguna ini dilakukan oleh perusahaan teknologi dengan menghubungkan desainer (developer) dengan para pengguna secara langsung, mengupayakan desain yang interaktif, dan menyediakan media umpan balik dari pengguna (Elkerton, 2012). Upayaupaya tersebut telah diupayakan oleh Qiscus untuk memastikan klien mereka mendapatkan produk yang sesuai harapan.

Strategi Qiscus yang dirumuskan di tengah uncertainty yang tinggi bertujuan untuk mencapai keunggulan produk maupun layanan sehingga menjadi pilihan utama bagi konsumen. Qiscus melakukan langkah-langkah strategis untuk memastikan produk mereka berbeda dan lebih baik dengan produk penyedia jasa 
yang lain sebagaimana yang dinyatakan oleh Barney (1991) bahwa keunggulan kompetitif dapat diraih ketika perusahaan menerapkan strategi yang menciptakan nilai yang menjadikannya berbeda dan tidak dapat diikuti oleh kompetitor potensialnya.

Pendanaan pada perusahaan startup memegang peranan yang menentukan berkembang atau tidaknya suatu perusahaan. Temuan Garg dan Shivam (2017) menunjukkan bahwa tingkat kegagalan startup sangat tinggi pada tahap pendanaan awal. Qiscus mampu melewati badai krisis keuangan akibatnya kurangnya pendanaan sebanyak 2 kali. Hal ini dapat dilakukan karena Qiscus mampu melakukan prediksi keuangan dan menyusun rencana yang jangka pendek 3 bulan. Hal ini membuat Qiscus dapat relatif siap menghadapi situasi keterbatasan dana. Selain itu, brand image Qiscus yang cukup kuat membuat mereka telah mampu melakukan pendekatan kepada para investor potensial.

Strategi yang diuraikan $\mathrm{di}$ atas merupakan strategi yang bersifat eksternal yang bertujuan untuk menjaga keunggulan di tengah persaingan yang ada sehingga konsumen bertahan dan berkembang. Strategi eksternal tersebut dapat dilakukan dengan dukungan internal yang mantap. Manuver-manuver yang dilakukan oleh Qiscus dalam upayanya melakukan ekspansi dapat berjalan dengan baik karena didukung oleh sumber daya manusia yang kompeten, memiliki komitmen, dan engaged dengan perusahaan. Hal ini dapat dibangun dengan mengembangkan high involvement organization dalam perusahaan.

High Involvement Organization dapat menjadi fondasi awal bagi perusahaan startup untuk melakukan strategi-strategi lainnya. Di antaranya strategi untuk memperluas pasar, beradaptasi dengan perubahan teknologi, maupun bersaing dengan kompetitor. Founder dapat melakukan berbagai manuver dan perubahan dengan lebih mantap ketika terdapat dukungan dari seluruh elemen organisasi. Ukuran tim pada perusahaan startup yang pada umumnya masih relatif kecil membuat perusahaan startup harus mampu memaksimalkan sumber daya yang tersedia. Hal ini dapat dilakukan dengan membangun tim yang memiliki kompetensi, engaged dan berkomitmen terhadap perusahaan. Aset ini akan menjadi sumber kekuatan bagi organisasi dalam menghadapi ketidakpastian dan mencapai keunggulan kompetitif.

High Involvement Organization telah banyak terbukti berpengaruh positif terhadap pencapaian organisasi. Cummings \& Worley (2009) menghimpun berbagai dampak positif penerapan strategi ini terhadap penjualan produk per karyawan, rendahnya angka turnover, tingginya quality of worklife para pekerja, dan produktivitas organisasi secara umum. Lebih lanjut, engagement, yang merupakan dampak dari dibangunnya $\mathrm{HIO}$ telah banyak terbukti berkorelasi positif terhadap produktivitas organisasi. Whittington dan Galpin (2010) mengajukan model yang menjelaskan bagaimana hubungan antara full ranged leadership, enriched job, trust, dan goal setting terhadap performa. Keempat unsur tersebut akan menimbulkan perasaan terlibat dan memiliki (engaged) karyawan terhadap organisasi, dan akhirnya perasaan tersebut melahirkan antusiasme dalam bekerja dan akhirnya meningkatkan performa, baik individu maupun organisasi.

\section{Kesimpulan}


Secara garis besar, strategi Qiscus untuk dapat bertahan di tengah ketidakpastian dan mencapai keunggulan kompetitif dapat terbagi menjadi dua tema besar yaitu, penguatan internal dan ekspansi eksternal. Strategi internal maupun eksternal Qiscus di atas dapat dilakukan dengan lebih mudah dengan adanya partisipasi dan keterlibatan aktif seluruh komponen organisasi. Strategi internal berupa high involvement organization akan menjadi dasar kekuatan bagi berbagai perusahaan yang menghadapi situasi ketidakpastian yang tinggi. Kekuatan internal berupa soliditas tim, komitmen dan kekayaan sumber ide akan menjadi penopang organisasi untuk menghadapi tantangan bisnis eksternal. Tingginya partisipasi ini telah teruji berhubungan positif dengan komitmen dan pencapaian tujuan organisasi (Medlin \& Green, 2008; Whittington \& Galpin, 2010). Berkaca pada temuan tersebut perlu bagi perusahaan yang hidup dalam lingkungan yang sama untuk membangun kekuatan internal berupa partisipasi yang tinggi dari seluruh anggota perusahaan.

\section{Saran}

Berdasarkan hasil temuan ini, saran utama peneliti bagi para pelaku startup adalah untuk menyiapkan perusahaannya agar siap berubah merespon situasi yang ada (pivot). Kesiapan berubah dapat dibangun dengan meningkatkan partisipasi dan keterlibatan anggota dalam perumusan strategi dan pengambilan keputusan organisasi (high involvement organization). Upaya ini dapat diupayakan dengan mengomunikasikan konteks kepada karyawan. Langkah ini dilakukan dengan menjaga komunikasi antara pimpinan dengan anggota organisasi mengenai tujuan, target, dan tantangan yang sedang dihadapi perusahaan.
Selanjutnya, peneliti menyarankan bagi peneliti berikutnya untuk mengkaji organisasi yang hidup dalam ketidakpastian yang tinggi dengan model bisnis yang berbeda. Upaya ini dapat dilakukan untuk melihat apakah terdapat pola atau kesamaan dengan hasil yang ditemukan pada perusahaan startup dengan model bisnis yang lain. Upaya ini akan semakin membuka pemahaman dunia akademis mengenai perilaku organisasi dalam merespons situasi ketidakpastian yang tinggi.

\section{Kepustakaan}

Asosiasi Penyelenggara Jasa Internet Indonesia (APJII). (2016). Penetrasi $\mathcal{E}$ perilaku pengguna internet Indonesia. Jakarta.

Balaji, T. S., Arumugham, J., Cavrak, S., Knuycky, L., \& Lutz, M. (2015). Structural equation modeling in user experience research: Two case studies. Proceedings of the Human Factors and Ergonomics Society, 2015-January, 448452. doi: $\underline{10.1177 / 1541931215591095}$

Barney, J. (1991). Firm resources and sustained competitive advantage. Journal of Management, 17(1), 99-120. doi: $10.1177 / 014920639101700108$

Birt, L., Scott, S., Cavers, D., Campbell, C., \& Walter, F. (2016). Member checking : A tool to enhance trustworthiness or merely a nod to validation? Qualitative Health Research, 26(13). doi: $\underline{10.1177 / 1049732316654870}$

Čalopa, M. K., Horvat, J., \& Lalić, M. (2014). Analysis of financing sources for startup companies. Management, 19(2), 1944.

Cater., \& Pujko, D. (2005). How competitive advantage influences firm 
performance: The case of Slovenian firms. Economic and Business Review for Central and South - Eastern Europe;, 7(2), 119-135.

Creswell, J. W. (2009). Research design. Los Angeles: Sage Publications.

Cummings, T. G. \& Worley, C. G. (2009) Organization development $\mathcal{E}$ change (Edisi kesembilan). South Western Cengage Learning, Mason.

Dess, G., \& Davis, P. (1984). Porter's (1980) generic strategies as determinats of strategic group membership and organizational performance. The Academy of Management Journal, 27(3), 467-488.

Elkerton, J. (2012). Supporting agile development with user centered design. In M. Resnick (Ed.), Proceedings of the Human Factors and Ergonomics Society 56th Annual Meeting -. Boston.

Garg, A. \& Shivam, A. K. (2017). Funding to growing start-ups. Research Journal of Social Sciences, 10(2), 22-31.

Hatta, A., Aryanto, A., \& Syeikh, A. (2016, September). Startup: Berlomba meraup konsumen dengan adu inovasi. Warta Ekonomi, 26-27.

Indah,P., \& Rizalulhaq, A. (2017). Indonesia E-Commerce summit EXPO (IESE) 2017: Kebangkitan E-Commerce Indonesia. Info Komputer, 42-43.

Medlin, B., \& Green, K. (2008). The relationship among goal setting, optimism, and engagement: The impact on employee performance. In Proceedings of the Academy of Culture, Communication and Conflict (Vol. 12, pp. 51-57). Tunica: Allied Academies International Conference.

Patton, M. Q. (2002). Qualitative research $\mathcal{E}$ evaluation methods. Thousand Oaks: Sage Publications.
Raj, M. P. M., \& Roy, S. (2015). Impact of brand image on consumer decisionmaking: A study on high-technology products. Global Business Review, 16(3), 463-477. doi: 10.1177/0972150915569934

Robbins, S., \& Barwell, N. (2002). Organization theory (Edisi keempat). NSW: Pearson Education.

Salamzadeh, A., \& Kesim, H. (2015). Startup companies: Life cycle and challenges startup companies: Life Cycle and Challenges. doi: 10.13140/RG.2.1.3624.8167

Salamzadeh, Aidin; Kirby, D. (2017). New venture creation: How start-ups grow. AD-Minister, 30(January-June), 9-99. doi: 10.17230/ad-minister.30.1

Shannassy, T. O. (2008). Sustainable competitive advantage or temporary competitive advantage improving understanding of an important strategy construct. Journal of Strategy and Management, 1(2), 168-180. doi: $\underline{10.1108 / 17554250810926357}$

Sitepu, S. N. (2017). Pengaruh Faktor internal terhadap keberhasilan start-up bisnis di kota surabaya. Jurnal Manajemen Teori dan Terapan/Journal of Theory and Applied Management, 10(1), 37. doi: 10.20473/jmtt.v10i1.5136

Srivastava, M., \& Kamdar, R. M. (2009). Brand image formation as a function of involvement and familiarity. Paradigm, 13(1), 84-90. doi: $\underline{10.1177 / 0971890720090111}$

Strauss, A., \& Corbin, J. (1990). Basics of qualitative research. London: Sage Publications.

Whittington, J. L., \& Galpin, T. J. (2010). The engagement factor: Building a highcommitment organization in a lowcommitment world. Journal of Bussiness 
Strategy, 31(5), 14-24. doi: 10.1108/02756661011076282

Yin, R. K. (2012). Application of case study research. Thousand Oaks: Sage Publications. 